\title{
A Preliminary Investigation on the Chromosome Aberrations in Acute Lymphoblastic Leukaemia Using Multiprobe Fluorescence In Situ Hybridization Panel
}

\section{Multiprob Floresan In Situ Hibridizasyon Paneli Kullanılarak Akut Lenfoblastik Lösemide Kromozom Aberasyonları Üzerine Bir Ön Çalışma}

(i) Bengisu GÖKKAYA1,2, id Sezen ATASOY1,3, ib Ayşe ÇIRAKOĞLU44, id Yelda TARKAN ARGÜDEN4, io R. Dilhan KURU4

(i) Şükriye YILMAZ ${ }^{4}$, (D) Şeniz ÖNGÖREN 5 , id Ayhan DEVIREN ${ }^{4}$

1'stanbul University, Aziz Sancar Institute of Experimental Medicine, Department of Genetics, İstanbul, Turkey

${ }^{2}$ MDX Clinical Research, Education and Consultancy Co. Ltd, İstanbul, Turkey

33Bezmialem Vakıf University Faculty of Pharmacy, Department of Biochemistry, İstanbul, Turkey

4ìstanbul University-Cerrahpaşa, Cerrahpaşa Medical Faculty, Department of Medical Biology, İstanbul, Turkey

Iİstanbul University-Cerrahpasa, Cerrahpasa Medical Faculty, Department of Internal Medicine, Hematology Section, İstanbul, Turkey

\section{ABSTRACT}

Objective: Acute lymphoblastic leukemia (ALL) is a disease related to the overproduction of immature lymphocytes. For diagnosis and classification of ALL, recognizing chromosome aberrations using conventional cytogenetic analysis (CCA) is essential. However, limited ability of CCA to capture cryptical chromosomal aberrations is a major drawback. The aim of this study was to investigate recurrent aberrations in patients with ALL with normal karyotype or unsuccessful karyotyping using the fluorescence in situ hybridization (FISH) method.

Methods: Ten patients with ALL were included in this study. CCA was done according to the standart protocols, and then, multiprobe FISH panel was used for analyzing different chromosomal regions located on $12 \mathrm{p} 13.2 / 21 \mathrm{q} 22.12$, 9q34.11-q34.12/22q11.22-q11.23, 9p21.3, 19p13.3, 11q23.3, 8q24.21, 14q32.33, 10p11.1-q11.1, $17 \mathrm{p} 11.1-\mathrm{q} 11.1$ and $4 \mathrm{q} 12$.

Results: Analyses of the specific chromosomal regions with FISH assay revealed undetected chromosome rearrangements. Among all the cases, four of them harbored chromosomal abnormalities. $M Y C$, $T C F 3, I G H$ rearrangements, $C D K N 2 A$ deletion and hyperdiploidy were detected in the study.

\section{ÖZ}

Amaç: Akut lenfoblastik lösemi (ALL), olgunlaşmamış lenfositlerin aşırı üretimi ile ilişkilendirilen bir hastalıktır. ALL'nin teşhisi ve sınıflandırılmasında klasik sitogenetik analizi (KSA) ile kromozom anomalilerinin tanımlanması önem teşkil etmektedir. Fakat KSA'nın kriptik kromozom değişimlerini saptamadaki sınırlılığı, bu yöntemin büyük bir dezavantajıdır. Yapılan çalışmanın amacı; floresan in situ hibridizasyon (FISH) yöntemi kullanılarak normal karyotipli veya değerlendirilecek metafazı olmayan ALL hastalarında mevcut kromozom anomalilerini araştırmaktır.

Yöntemler: Çalışmaya 10 ALL hastası dahil edildi. KSA, standart protokollere göre uyguland, ardından $2 \mathrm{p} 13.2 / 21 \mathrm{q} 22.12$, 9q34.11q34.12/22q11.22-q11.23, 9p21.3, 19p13.3, 11q23.3, 8q24.21, $14 q 32.33,10 \mathrm{p} 11.1-\mathrm{q} 11.1,17 \mathrm{p} 11.1-\mathrm{q} 11.1$ ve $4 \mathrm{q} 12$ 'de yer alan kromozom bölgelerinin analizi için multiprob FISH paneli kullanıldı.

Bulgular: Spesifik kromozom bölgelerinin FISH metodu ile analizi, önceden saptanmamış kromozom düzenlemelerinin bulunduğunu ortaya çıardı. İncelenen tüm olguların dördünde kromozom anomalileri tespit edildi. Çalışmada $M Y C, T C F 3, I G H$ genlerinin yeniden düzenlemeleri, $C D K N 2 A$ delesyonu ve hiperdiploidi tespit edildi.
Address for Correspondence: Sezen ATASOY, Bezmialem Vakıf University Faculty of Pharmacy, Department of Biochemistry, ìstanbul, Turkey

E-mail: satasoy@bezmialem.edu.tr ORCID ID: orcid.org/0000-0001-5063-5053

Cite this article as: Gökkaya B, Atasoy S, Çırakoğlu A, Tarkan Argüden Y, Kuru RD, Yılmaz Ş, Öngören Ş, Deviren A. A Preliminary Investigation on the Chromosome Aberrations in Acute Lymphoblastic Leukaemia Using Multiprobe Fluorescence In Situ Hybridization Panel. Bezmialem Science 2022;10(3):370-5
Received: 27.11 .2020

Accepted: 21.04.2021 
Conclusion: Diagnostic sensitivity of FISH probes in comparison with CCA is effective in the detection of multiple chromosomal rearrangements with prognostic significance. For the improvement of the cytogenetic examination and achieving optimum results for patients with ALL, FISH panels are needed to be used combining with conventional cytogenetics routinely.

Keywords: Acute lymphoblastic leukemia, cytogenetics, fluorescence in situ hybridization, chromosome aberrations
Sonuç: Klasik sitogenetik analiz ile karşılaştırıldığında, FISH problarının tanıdaki duyarlılığı prognostik önemi olan çoklu kromozom anomalilerinin saptanmasında yararlıdır. Sitogenetik incelemelerin geliştirilmesi ve ALL olgularında en iyi test sonuçlarının elde edilmesi için, rutinde FISH panellerinin klasik sitogenetik yöntemler ile birleştirilerek kullanılması gerekmektedir.

Anahtar Sözcükler: Akut lenfoblastik lösemi, sitogenetik, floresan in situ hibridizasyonu, kromozom aberasyonları

\section{Introduction}

Acute lymphoblastic leukemia (ALL) is a type of disease characterized by overproduction of malignant and immature lymphocytes. As a consequence of failure to produce mature blood cells and uncontrolled proliferation of lymphoblasts, it spreads to the blood and metastasizes other areas (1). Although the cause of ALL remains unknown, it is thought that various complex mechanisms such as chromosomal damage due to physical or chemical exposure are required for the development of the disease (2).

Conventional cytogenetic analysis (CCA) plays an essential role in the identification of structural and numerical chromosome aberrations that are useful prognostic indicators in patients with ALL. Chromosome aberrations are observed in 60$85 \%$ of patients with ALL (3). Hyperdiploidy, hypodiploidy, $\mathrm{t}(9 ; 22)(\mathrm{q} 34 ; \mathrm{q} 11.2) \quad$ [BCR-ABL1], $\mathrm{t}(\mathrm{v} ; 11 \mathrm{q} 23.3) \quad$ MLL rearrangements, $\mathrm{t}(12 ; 21)(\mathrm{p} 13 ; \mathrm{q} 22)$ [ETV6-RUNX1], $\mathrm{t}(1 ; 19)$ (q23;p13.3) [TCF3-PBX1], t(5;14)(q31;q32) [IL3-IGH] and intrachromosomal amplification in chromosome 21 (iAMP21) are commonly observed and play significant role in the classification and prognosis of ALL (4). Inadequate specimens, low mitotic index and difficulty of obtaining high-quality metaphases in bone marrow (BM) are impeded or rendered the CCA impossible. Furthermore, some of the structural abnormalities, such as t(12;21) [ETV6-RUNX1] may exist cryptically and be undetectable by CCA. Since fluorescence in situ hybridization (FISH) allows determination of chromosomal changes at interphases besides metaphases with high specificity and sensitivity, it is advantageous for the examination of ALL related abnormalities in the patients with low mitotic activity or normal karyotype $(5,6)$. FISH panels using different probe combinations are available to detect common rearrangements for ALL simultaneously (7).

In our study, we aimed to investigate recurrent aberrations in patients with ALL with normal karyotype or unsuccessful karyotyping using the FISH method. We used a multiprobe panel carrying probes for $\mathrm{t}(12 ; 21)$ [ETV6-RUNX1], $\mathrm{t}(9 ; 22)$ [BCR-ABL1], deletion of 9p21.3 (CDKN2A), rearrangements of TCF3 located on 19p13.3, MLL located on 11q23.3, MYC located on $8 \mathrm{q} 24.21$, and IGH located on $14 \mathrm{q} 32.33$, also enumeration probes for chromosomes 4, 10 and 17.

\section{Methods}

\section{Patients}

Ten patients with normal karyotype $(\mathrm{n}=7)$ or karyotyping failure $(n=3)$ were selected for this study from our patients with ALL whose BM samples were referred by hematology section for CCA. Equal patients of males and females were included in the study and three of them were patients with childhood ALL. Peripheral blood (PB) samples of healthy individuals $(n=5)$ were used for establishing cutoff values. The median ages of patient and control groups were 24 and 23 , respectively. The characteristics of the patients are given in Table 1 . The informed consent forms were obtained in accordance with the Declaration of Helsinki and the study had the permission of our University's Research Ethics Committee (approval number: 135385).

\section{Conventional Cytogenetics Analysis}

Twenty-four-hour and $48 \mathrm{~h}$ unstimulated BM cultures and 72 $h$ unstimulated PB cultures were performed according to the standard protocols and banding was applied to slides using Giemsa-Trypsin-Leishman (GTL) method (8). To perform conventional karyotyping, at least 15 metaphases were analyzed per patient and karyotypes were defined according to the International System for Human Cytogenetic Nomenclature (ISCN 2016) (9).

\section{Fluorescence In Situ Hybridization}

For FISH assay, Chromoprobe multiprobe ALL panel (Cytocell Ltd, Cambridge, UK) consisted of 12p13.2 (ETVG)/21q22.12 (RUNX1), 22q11.22 (BCR)/9q34.11-q34.12 (ABL1), 9p21.3 (CDKN2A), 19p13.3 (TCF3), 11q23.3 (MLL), 8q24.21 (MYC), $14 \mathrm{q} 32.33(I G H), 10 \mathrm{p} 11.1-\mathrm{q} 11.1$ (centromere of chromosome 10), 17p11.1-q11.1 (centromere of chromosome 17) and $4 \mathrm{q} 12$ (CHIC2, chromosome 4) chromosomal regions were used. The experimental protocols were performed according to the previous study and manufacturer's instructions (10). Slides were analyzed under the fluorescence microscope (Olympus BX51, Tokyo, Japan) with filter sets (TxRed, FITC, Aqua, DAPI). FISH scoring was performed independently by two investigators. The cutoff values were determined by examination of control subjects and calculated using inverse beta distribution (betainv) (11).

\section{Results}

The FISH assay revealed cytogenetically undetected chromosome rearrangements in target regions of the multiprobe panel in our patient group (Figure 1). The results are summarized in Table 1. 


\section{MYC}

The MYC rearrangements were detected higher than cutoff values (13\%) in two patients; Case No. P3 (25\%), and Case No.P5 (25\%).

\section{CDKN2A}

Deletions of the CDKN2A region were found in only Case No. P2 (28\%) (Cutoff value: 10\%).

\section{TCF3}

The rearrangements of TCF3 were detected in two patients; Case No. P2 (18\%) and Case No. P8 (28\%) (Cutoff value: 16\%)
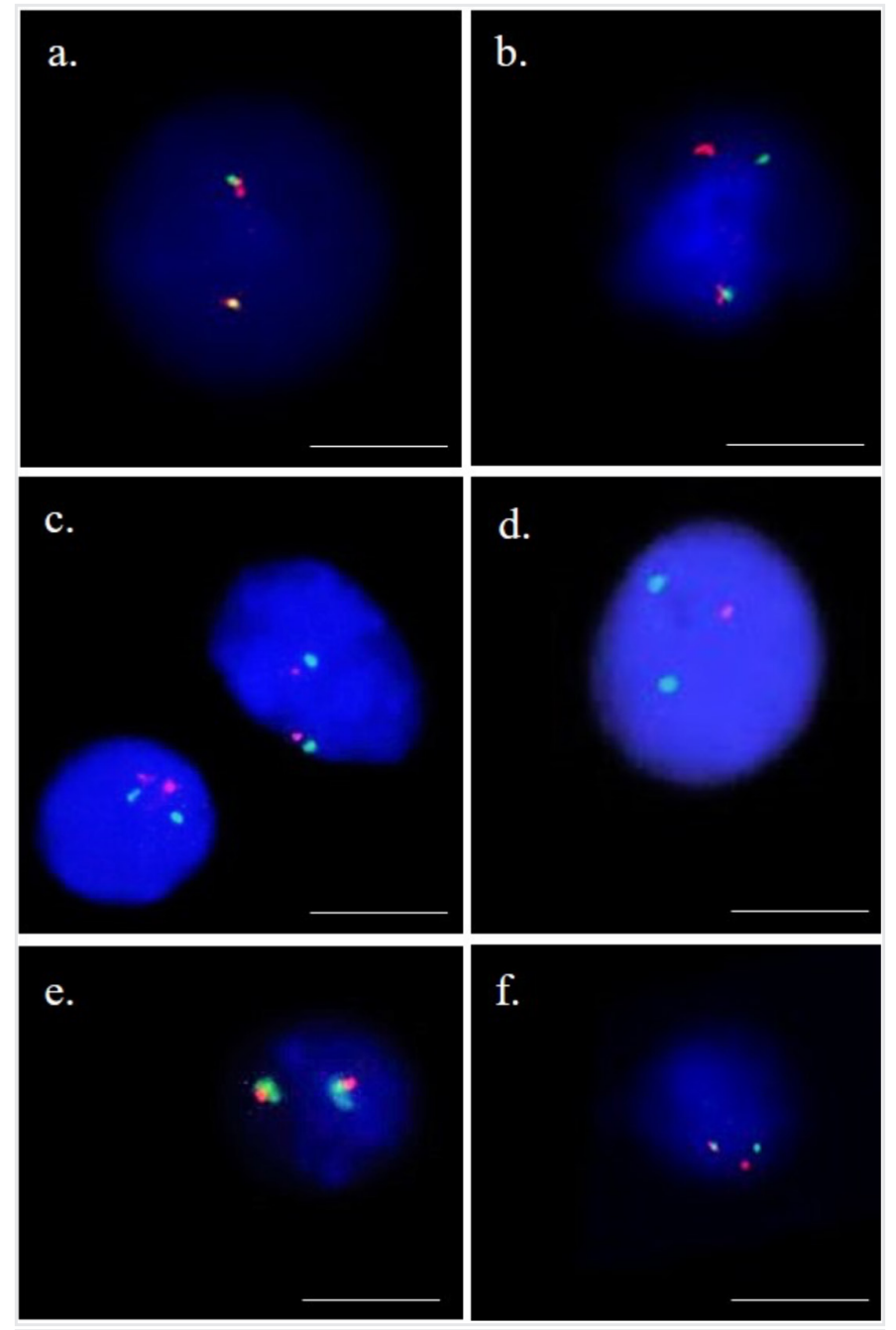

Figure 1. Examples of interphase nuclei with $M Y C$, CDKN2A and IGH probe signals, signifying normal cells (a, c and e, respectively), a MYCrearrangement (b), a CDKN2 deletion (d) and an IGH rearrangement (f) (objective, $\mathrm{x} 100$ ). Rearrangements have led to the separation of green and red signals, whereas deletion is seen with only one red signal on a chromosome and absent signal on the other chromosome (scale bar: $10 \mu \mathrm{m}$ )

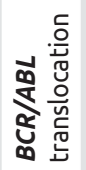

离高

긍

กั้

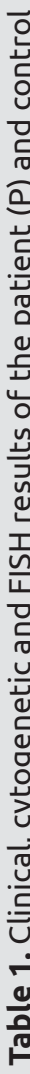

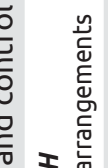

志正

之帘

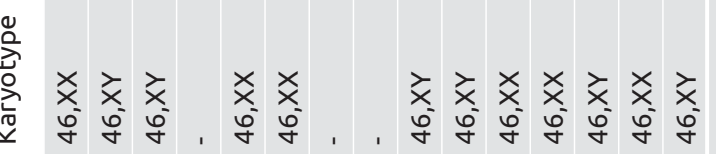

$\frac{n}{\text { ก }}$

员

离 (1)

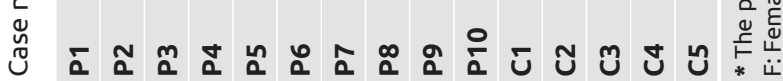




\section{Chromosome 4}

The cutoff values for gains and losses of the CHIC2 region of chromosome 4 were determined separately as $6 \%$ for gains and $5 \%$ for losses. All of the patients were negative for both losses and gains of the CHIC2 region.

\section{Centromere 10}

The cutoff values for gains of centromere 10 were $10 \%$ and $6 \%$ for the losses. Only case P2 was positive for the gain of chromosome $10(32 \%)$.

\section{Centromere 17}

The cutoff values for gains of centromere 17 were $6 \%$ and $13 \%$ for the losses. While there was no patient with the gain of chromosome 17, two patients were positive for loss; case no. P5 (15\%) and case no. P8 (14\%).

\section{ETV6/RUNX1}

The cutoff value was $3 \%$ and none of the patients had ETVG/ RUNX1 translocation.

\section{MLL}

The cutoff value was $9 \%$ and none of the patients had $M L L$ rearrangements.

\section{BCR/ABL1}

The cutoff value was $3 \%$ and none of the patients had $B C R /$ $A B L 1$ translocation.

\section{IGH}

The rearrangements of $I G H$ were detected in two patients; case no. P3 (19\%) and case no. P8 (19\%) (cutoff value 17\%).

While Case P2 (TCF3, CDKN2A and gain of chromosome 10) and Case P8 (TCF3, IGH and loss of chromosome 17) had three abnormalities, Case P3 (MYC and $I G H)$ and Case P5 (MYC and loss of chromosome 17) had two abnormalities. The other six patients had no abnormalities for the multiprobe panel. TCF3, MYC, IGH rearrangements, and loss of chromosome 17 were detected twice in the study while $C D K N 2 A$ deletion was observed once. MLL rearrangements, translocations of ETVG/ RUNX1 and BCR/ABL1, gains of chromosomes 4 and 17, losses of chromosomes 4 and 10 were not detected in this study.

\section{Discussion}

Multiprobe FISH panels provide an advantage to detect diseasespecific genetic abnormalities that do not only have prognostic significance but also play roles in classification, follow-ups, and treatment of hematological malignancies (7). Previous studies showed that using FISH panels was effective to detect additional chromosomal abnormalities not detected by CCA in nearly $50 \%$ of patients with ALL $(12,13)$. In this study, a FISH panel including probes for common abnormalities for ALL was applied to the 10 patients with ALL with normal karyotype or karyotyping failure. The reason for failure in conventional karyotyping in our 3 patients could either be culture failure, insufficient metaphase quality, or technical problems in trypsin digestion and staining stages, besides the known difficulty of obtaining chromosomes in ALL. However, in these patients, the FISH assay showed efficiency for identifying the chromosome aberrations. Chromosomal abnormalities were observed in 4 (40\%) of the patients using FISH method. All of these patients had two or three abnormalities. Although adult and childhood patients with ALL were evaluated as separate groups generally, we discussed our adult and childhood patients altogether because of the smallness of our study group. Case P8 was our only childhood patient with positive FISH findings and had three abnormalities (TCF3 rearrangements, CDKN2A deletion, and hyperdiploidy).

The ETV6/RUNX1 translocation is the most frequent abnormality in childhood B-cell ALL (B-ALL) and associated with favorable outcome $(4,14,15)$. It is difficult to detect this cryptic translocation by CCA $(16,17)$. Previous studies with FISH panels reported frequent occurrences of ETV6/RUNX1 translocation (10-44.3\%) $(6,12,18-21)$. However, there were no findings of ETV6/RUNX1 translocation in our patients. This was probably due to small number of patients, 3 of whom were in childhood.

The $B C R / A B L 1$ fusion caused by $\mathrm{t}(9 ; 22)$ (q34; 111$)$ is present in $15-50 \%$ of adults and $3-5 \%$ of patients with childhood ALL and it is associated with poor outcome $(4,16,22)$. CCA has relatively high $(80 \%)$ sensitivity for detection of $\mathrm{t}(9 ; 22)(\mathrm{q} 34 ; \mathrm{q} 11)$ $(4,13,18)$. Similar to karyotypic results, we did not detect $B C R /$ $A B L 1$ translocation in any of the patients by FISH either.

The $M Y C$ rearrangements are usually found as translocations between $M Y C$ locus (8q24) and $I G H$ heavy and light chain gene loci located on $14 \mathrm{q} 32,2 \mathrm{p} 12$, and $22 \mathrm{q} 11$, respectively. Rearrangements of $M Y C$ are characteristic in Burkitt lymphoma cytogenetics, also present in subtypes of mature B-cell neoplasms (less than 5\% in both adults and children) $(16,23,24)$. Kim BR et al. found gains of $M Y C$ in two (20\%) patients with ALL using FISH panel including $M Y C$ rearrangement probe (18). In our study, $M Y C$ rearrangements were found in two patients (Cases $\mathrm{P} 3$ and $\mathrm{P} 5)$ too. In Case P3, both $M Y C$ and $I G H$ rearrangements were observed. The coexistence of these two rearrangements points out to the existence of $\mathrm{t}(8 ; 14)$. The closeness of the ratios of $M Y C(25 \%)$ and $I G H(19 \%)$ rearrangements also support this conclusion. The other patient (Case P5) with $M Y C$ rearrangement had no $I G H$ rearrangement, but she had monosomy 17 meaning hypodiploidy. It was commonly assumed in previous studies that isolated $M Y C$ rearrangements were rare in B-ALL and we did not observe $M Y C$ rearrangement as sole abnormality either $(23,24)$.

\section{Study Limitations}

Although $I G H$ rearrangements are frequent in lymphomas and mature leukemias, several studies have revealed that these rearrangements account for 5\% of patients with ALL with both B-cell and T-cell, mostly in adolescents and young adults. Multiple partner genes are involved in $I G H$ translocations $(4,25,26)$. We found that $I G H$ rearrangements coexisted with TCF3 rearrangements and monosomy 17 in Case P8, and MYC rearrangements in Case $\mathrm{P} 3$. In previous studies, $T C F 3$ has not 
been reported among partner genes of $I G H$ translocations $(25,26)$.

The TCF3 gene locus are involved in $\mathrm{t}(1 ; 19)(\mathrm{q} 23 ; \mathrm{p} 13)$ and $\mathrm{t}(17 ; 19)(\mathrm{q} 21 ; \mathrm{p} 13)$. While $\mathrm{t}(1 ; 19)(\mathrm{q} 23 ; \mathrm{p} 13)$ has been reported in $2 \%$ of patients with childhood ALL and $6 \%$ of patients with adult ALL and associated with intermediate-risk, $t(17 ; 19)(\mathrm{q} 21 ; \mathrm{p} 13)$ is seen more rarely, in $<0.1 \%$ of patients with B-cell precursor ALL (BCP-ALL) $(4,27)$. We observed rearrangements of TCF3 in combination with $C D K N 2 A$ deletion and hyperdiploidy in one further patient (Case P2) apart from Case P8 discussed above. $C D K N 2 A / 2 B$ deletions are frequent (30-50\%) abnormalities in both patients with childhood ALL and patients with adult ALL and are associated with poor prognosis (28). Hyperdiplody is another frequent abnormality in childhood ALL, and high hyperdiploidy is considered a good prognostic factor $(4,16,22)$. Case P8 was our childhood patient, and had CDKN2A deletions and hyperdiploidy.

\section{Conclusion}

In our study, despite the small number of patients, chromosomal abnormalities related to ALL were found in a significant amount of patients with normal karyotype or unsuccessful karyotyping. Using multiprobe FISH panels was effective in the detection of multiple chromosomal rearrangements with prognostic significance simultaneously. Of all the patients with ALL we analyzed, multiprobe FISH was able to detect $M Y C$, TCF3 and $I G H$ rearrangements, deletion of the $C D K N 2 A$, gains of centromere 10, losses of the centromere 17 . Identification of these chromosome abnormalities in hematological malignancies, especially in ALL, may provide prognostic value for treatment planning, response or follow-up. Therefore, we suggest that FISH panels are needed to be used combining with conventional cytogenetics routinely to achieve optimum results for patients with ALL.

\section{Ethics}

Ethics Committee Approval: The informed consent forms were obtained in accordance with the Declaration of Helsinki and the study had the permission of our University's Research Ethics Committee (approval number: 135385).

Informed Consent: Obtained.

Peer-review: Externally peer reviewed.

\section{Authorship Contributions}

Concept: B.G., S.A., A.Ç., Y.T.A., R.D.K., Ş.Y., Ş.Ö., A.D., Design: B.G., S.A., A.Ç., Y.T.A., R.D.K., Ş.Y., Ş.Ö., A.D., Data Collection or Processing: B.G., S.A., A.Ç., Y.T.A., R.D.K., Ş.Y., Ş.Ö., A.D., Analysis or Interpretation: B.G., S.A., A.Ç., Y.T.A., R.D.K., Ş.Y., Ş.Ö., A.D., Literature Search: B.G., S.A., A.Ç., Y.T.A., A.D., Writing: B.G., S.A., A.Ç., Y.T.A., R.D.K., Ş.Y., A.D.

Conflict of Interest: No conflict of interest was declared by the authors.
Financial Disclosure: This work was financially supported by İstanbul University Scientific Research Projects (project no: 57448).

\section{References}

1. Malard F, Mohty M. Acute lymphoblastic leukaemia. Lancet 2020;395:1146-62.

2. Iacobucci I, Mullighan CG. Genetic Basis of Acute Lymphoblastic Leukemia. J Clin Oncol 2017;35:975-83.

3. Shago M. Recurrent Cytogenetic Abnormalities in Acute Lymphoblastic Leukemia. Methods Mol Biol. 2017;1541:257-78.

4. Moorman AV. New and emerging prognostic and predictive genetic biomarkers in B-cell precursor acute lymphoblastic leukemia. Haematologica 2016;101:407-16.

5. Haferlach C, Rieder H, Lillington DM, Dastugue N, Hagemeijer A, Harbott J, et al. Proposals for standardized protocols for cytogenetic analyses of acute leukemias, chronic lymphocytic leukemia, chronic myeloid leukemia, chronic myeloproliferative disorders, and myelodysplastic syndromes. Genes Chromosomes Cancer 2007;46:494-9.

6. Nordgren A, Schoumans J, Soderhall S, Nordenskjold M, Blennow E. Interphase fluorescence in situ hybridization and spectral karyotyping reveals hidden genetic aberrations in children with acute lymphoblastic leukaemia and a normal banded karyotype. Br J Haematol 2001;114:786-93.

7. Sreekantaiah C. FISH panels for hematologic malignancies. Cytogenet Genome Res 2007;118:284-96.

8. Silva M, de Leeuw N, Mann K, Schuring-Blom H, Morgan S, Giardino D, et al. European guidelines for constitutional cytogenomic analysis. Eur J Hum Genet 2019;27:1-16.

9. Nomenclature ISCoHC. ISCN: an international system for human cytogenomic nomenclature (2016): Karger; 2016.

10. Atasoy S, Erturan SS, Yilmaz N, Kuru D, Cirakoglu A, Yilmaz S, et al. Analysis of Chromosome 3, 7 and 8 Centromeric Regions in Bronchial Lavage Specimens by FISH. Turk Thorac J 2016;17:141-7.

11. Dowling PK. Mathematics for the cytogenetic technologist. The AGT Cytogenetics Laboratory Manual 2017:937-74.

12. Kim SR, Kim HJ, Kim SH. [Clinical utility of fluorescence in-situ hybridization profile test in detecting genetic aberrations in acute leukemia]. Korean J Lab Med 2009;29:371-8.

13. Kwon WK, Lee JY, Mun YC, Seong CM, Chung WS, Huh J. Clinical utility of FISH analysis in addition to G-banded karyotype in hematologic malignancies and proposal of a practical approach. Korean J Hematol 2010;45:171-6.

14. Woo JS, Alberti MO, Tirado CA. Childhood B-acute lymphoblastic leukemia: a genetic update. Exp Hematol Oncol 2014;3:16.

15. Taylor J, Xiao W, Abdel-Wahab O. Diagnosis and classification of hematologic malignancies on the basis of genetics. Blood 2017;130:410-23.

16. Kebriaei P, Anastasi J, Larson RA. Acute lymphoblastic leukaemia: diagnosis and classification. Best Pract Res Clin Haematol 2002;15:597-621. 
17. Najfeld V. Diagnostic application of FISH to hematological malignancies. Cancer Invest 2003;21:807-14.

18. Kim BR, Choi JL, Kim JE, Woo KS, Kim KH, Kim JM, et al. Diagnostic utility of multiprobe fluorescence in situ hybridization assay for detecting cytogenetic aberrations in acute leukemia. Ann Lab Med 2014;34:198-202.

19. Hutspardol S, Pakakasama S, Kanta K, Nuntakarn L, Anurathapan $\mathrm{U}$, Sirachainan N, et al. Interphase-FISH screening for eight common rearrangements in pediatric B-cell precursor acute lymphoblastic leukemia. Int J Lab Hematol 2013;35:406-15.

20. Harrison CJ, Moorman AV, Barber KE, Broadfield ZJ, Cheung $\mathrm{KL}$, Harris RL, et al. Interphase molecular cytogenetic screening for chromosomal abnormalities of prognostic significance in childhood acute lymphoblastic leukaemia: a UK Cancer Cytogenetics Group Study. Br J Haematol 2005;129:520-30.

21. Andreasson P, Hoglund M, Bekassy AN, Garwicz S, Heldrup J, Mitelman F, et al. Cytogenetic and FISH studies of a single center consecutive series of 152 childhood acute lymphoblastic leukemias. Eur J Haematol 2000;65:40-51.

22. Terwilliger T, Abdul-Hay M. Acute lymphoblastic leukemia: a comprehensive review and 2017 update. Blood Cancer J 2017;7:e577.

23. Navid F, Mosijczuk AD, Head DR, Borowitz MJ, Carroll AJ, Brandt $\mathrm{JM}$, et al. Acute lymphoblastic leukemia with the $(8 ; 14)(\mathrm{q} 24 ; \mathrm{q} 32)$ translocation and FAB L3 morphology associated with a B-precursor immunophenotype: the Pediatric Oncology Group experience. Leukemia 1999;13:135-41.

24. Li Y, Gupta G, Molofsky A, Xie Y, Shihabi N, McCormick J, et al. B Lymphoblastic Leukemia/Lymphoma With Burkitt-like Morphology and IGH/MYC Rearrangement: Report of 3 Cases in Adult Patients. Am J Surg Pathol 2018;42:269-76.

25. Russell LJ, Enshaei A, Jones L, Erhorn A, Masic D, Bentley H, et al. IGH@ translocations are prevalent in teenagers and young adults with acute lymphoblastic leukemia and are associated with a poor outcome. J Clin Oncol 2014;32:1453-62.

26. Moorman AV, Schwab C, Ensor HM, Russell LJ, Morrison H, Jones L, et al. IGH@ translocations, CRLF2 deregulation, and microdeletions in adolescents and adults with acute lymphoblastic leukemia. J Clin Oncol 2012;30:3100-8.

27. Barber KE, Harrison CJ, Broadfield ZJ, Stewart AR, Wright SL, Martineau $M$, et al. Molecular cytogenetic characterization of TCF3 (E2A)/19p13.3 rearrangements in B-cell precursor acute lymphoblastic leukemia. Genes Chromosomes Cancer 2007;46:47886.

28. Zhang W, Kuang P, Liu T. Prognostic significance of CDKN2A/B deletions in acute lymphoblastic leukaemia: a meta-analysis. Ann Med 2019;51:28-40. 